\title{
Greenhouse Daylight Illuminance for Users' Satisfaction in Hot and Humid Climate
}

\author{
Amalina Safiah Jasni ${ }^{1}$, Sabarinah Sh Ahmad ${ }^{1}$, Mariam Felani Shaari', Ricardo B Sánchez² \\ ${ }^{1}$ Centre of Studies for Architecture, Faculty of Architecture, Planning and Surveying, \\ Universiti Teknologi MARA, Puncak Alam Campus, Selangor, Malaysia. \\ ${ }_{2}^{2}$ National Autonomous University of Mexico, Mexico City, Mexico.
}

amalinasafiah@gmail.com, sabar643@uitm.edu.my, mariamfelani@uitm.edu.my, sanchezrick99@comunidad.unam.mx Tel: +60126864673

\begin{abstract}
The greenhouse is vital to protect indoor crops from the harsh hot-humid climate. This study firstly identifies design attributes of greenhouses such as dimension, shapes, orientation, and shading. Secondly, it assesses the impacts of design attributes on the greenhouse daylight performance using VeluxVisualizer. The results showed an increase in the number of skylights caused higher average daylight illuminance in the greenhouse. All the models passed the requirement for plants with small sunlight claim between 7 and 9 hours per day. This study paves the way for energy-efficient buildings with the aid of building simulation to benefit the users.
\end{abstract}

Keywords: Greenhouse Design Features, Daylight Simulation, Hot and Humid Climate

eISSN: 2398-42870 2021. The Authors. Published for AMER ABRA cE-Bs by e-International Publishing House, Ltd., UK. This is an open access article under the CC BYNC-ND license (http://creativecommons.org/licenses/by-nc-nd/4.0/). Peer-review under responsibility of AMER (Association of Malaysian Environment-Behaviour Researchers), ABRA (Association of Behavioural Researchers on Asians/Africans/Arabians) and CE-Bs (Centre for Environment-Behaviour Studies), Faculty of Architecture, Planning \& Surveying, Universiti Teknologi MARA, Malaysia.

DOI: https://doi.org/10.21834/ebpj.v6i16.2711

\subsection{Introduction}

The deterioration of microclimate conditions contributes to agricultural vulnerability (Alam et al., 2019). A modern greenhouse protects and controls indoor crops from unwanted harsh outdoor environments compared with open-field farming. Large scale greenhouses crop cultivation is successfully implemented in the temperate climatic regions (Ghoule, et al., 2019). Meanwhile, the countries in the hot and humid climate of the subtropics and tropics still need to overcome their high temperature and humidity challenges. Operating a crop farming business indoors remains a challenge as a huge volume of electricity usage required causing restrictions for operating efficiency (Asiabanpour et al., 2018). This study aspires to help architects, agriculturalists, and farmers understand the requirements of greenhouse design attributes for Malaysian hot-humid climatic conditions.

\subsection{Aim and Objectives}

This paper aims to study the effects of greenhouse design attributes on the daylight performance for efficient operation in hot-humid Malaysian climate using computer simulations.

The objectives of this study are two ways:

i. to identify design attributes of greenhouse such as dimension, shapes, orientation, envelope materials and building shading strategies

eISSN: 2398-4287@ 2021. The Authors. Published for AMER ABRA cE-Bs by e-International Publishing House, Ltd., UK. This is an open access article under the CC BYNC-ND license (http://creativecommons.org/licenses/by-nc-nd/4.0/). Peer-review under responsibility of AMER (Association of Malaysian Environment-Behaviour Researchers), ABRA (Association of Behavioural Researchers on Asians/Africans/Arabians) and cE-Bs (Centre for Environment-Behaviour Studies), Faculty of Architecture, Planning \& Surveying, Universiti Teknologi MARA, Malaysia. 
ii. to assess the impacts of design attributes on the greenhouse daylight performance in Malaysia

\subsection{Literature Review}

Greenhouse agriculture means "food growth factories" or "protected agriculture" (Ghani et al., 2020). The application of greenhouse in Malaysia's lowlands' hot-humid climate protects vegetation from the extreme heat, wind, rain and unwanted pests to achieve an ideal vegetation growth environment (Shamshiri \& Ismail, 2014).

Lighting and heat are two of the most influential atmospheric factors that influence crop production, which require a large amount of energy usage. Light is vital in this structure for the research programmes and crop production (Shamshiri et al., 2018).

\subsection{Forms \& Configuration}

According to Ghani et al. (2019), structures with modified arch shapes could reduce the greenhouse cooling requirements in hot climates. Asymmetrical greenhouse roofs emit lesser incident solar radiation. Inversely. the traditional symmetrical greenhouse roofs emit higher solar radiation during the summer season as the asymmetrical greenhouse roofs would cause unequal solar radiation distribution (Ghani et al., 2019). The East-West greenhouse orientation is preferable, as it receives lesser sunlight and solar energy in contrast to the NorthSouth orientation. (Ghani et al., 2019). The external shading devices reduced the thermal radiation of the greenhouse by $15 \%$ during nighttime and $21 \%$ during the day (Abdel-Ghany et al., 2016). A greenhouse with $50 \%$ shaded roof can effectively drop $10^{\circ} \mathrm{C}$ of the indoor greenhouse temperature (Abdel-Ghany et al., 2016). The three most common cooling method used are natural ventilation, shading, and cooling through evaporation as they are convenient and low cost.

\subsection{Envelope material}

Envelope materials are the materials that shield vegetation from the harsh outdoor climate. The covering material also acts as a regulator of the light and heat transmission into the greenhouse (Ghani et al., 2019). Unnecessarily high solar radiation and the high value of the overall heat transfer coefficient (U-value) of greenhouse enclosure are two primary sources of unwanted heat gain (Pakari \& Ghani, 2019). Skylight allows daylight into the interior of the structure, reducing electrical lighting use and costs.(Yunus et al., 2010) and in the case of the study, allows the crops to grow well.

\subsection{Daylight}

Natural lighting offers better economic and energy consumption in buildings than artificial lighting (Kousalyadevi \& Lavanya, 2019). Daylight efficiency and visual comfort must complement each other to achieve a sustainable and yet safe environment, and the best way to achieve them is through passive design (Husain et al., 2020).

In one study, a hypothetical assessment was conducted on artificial lighting practice in a vertical farm, and it was concluded that a facility of $100,000 \mathrm{~m}^{2}$ would require $133,585,200 \mathrm{kWh}$, which is a large volume of electricity usage as an operating efficiency restricting factor (Asiabanpour et al., 2018). Large scale plant production requires a substantial amount of energy for artificial light for the growth of plants.

Table 1: Light intensity requirements for vegetable plants (Source: Bodolan \& Brătucu, 2013)

\begin{tabular}{lc}
\hline Plant Type & Light intensity (Lux) \\
\hline Demanding plant (cucurbits, bean, okra, solanaceous) & $8000-120000$ \\
Less demanding plants (root, bulb, cabbage, leafy peas.) & $4000-7000$ \\
Plants with small claims (green onions, perennial onions, beet) & $1000-3000$ \\
\hline & \\
\hline & Table 2: Requirements for vegetable plants sunlight hours (Source: Kim, 2019) \\
\hline Plant Type & Hours \\
\hline High sunlight (tomatoes, peppers, eggplant, melons, cucumber) & $6-8$ \\
Medium sunlight (broccoli, carrots, radishes, potatoes) & $4-6$ \\
Low sunlight (spinach, lettuce, Asian green, mustard greens, parsley, cabbage, scallion) & $3-4$ \\
\hline
\end{tabular}

Illuminance is the amount of light measurement spreading over and illuminating a region of a specified surface area (DOSH, 2018). During photosynthesis, illumination becomes the decisive factor, operating through different parameters such as intensity, duration, spectral composition (Bodolan \& Brătucu, 2013). Sunlight is crucial; however, various plants need a certain amount and intensity of illumination to grow. Table 1 shows the illuminance intensity requirements for vegetable plants by Brodolan \& Bratucu (2013)Nonetheless, some variety of plants cannot completely handle too much sunlight. Table1 shows the vegetable plants light intensity requirement by Brodolan \& Bratucu (2013). Table 2 shows the requirements for vegetable plants sunlight hours (Kim, 2019). Thus, using label guidelines as a reference is critical, and tailoring them corresponding to local conditions. (Kim, 2019)

\subsection{Building simulation}

The daylighting condition of the greenhouse building is determined and analysed using Daylight Visualizer simulation tool. It permits accurately simulate and quantify daylight levels in interiors with a comprehensive set of reading for analysis (Mohapatra et al., 2018). The algorithms are able to calculate ray traversal in any of the following ways. The different methods of ray tracing are useful for 
calculating illumination and obtaining the rendered pictures (Mohapatra et al., 2018). Some of the other researcher that use VELUX daylight visualizer are Kousalyadevi (2019) and Azzahra (2019).

\subsection{Methodology}

\subsection{Research Flow Chart}

Figure 1 shows the research flow chart for this study. Phase 1 consists of identifying suitable design attribute implementation based on literature review. Next, Phase 2 is an assessment of Daylight illuminance using VELUX Daylight Visualizer software.

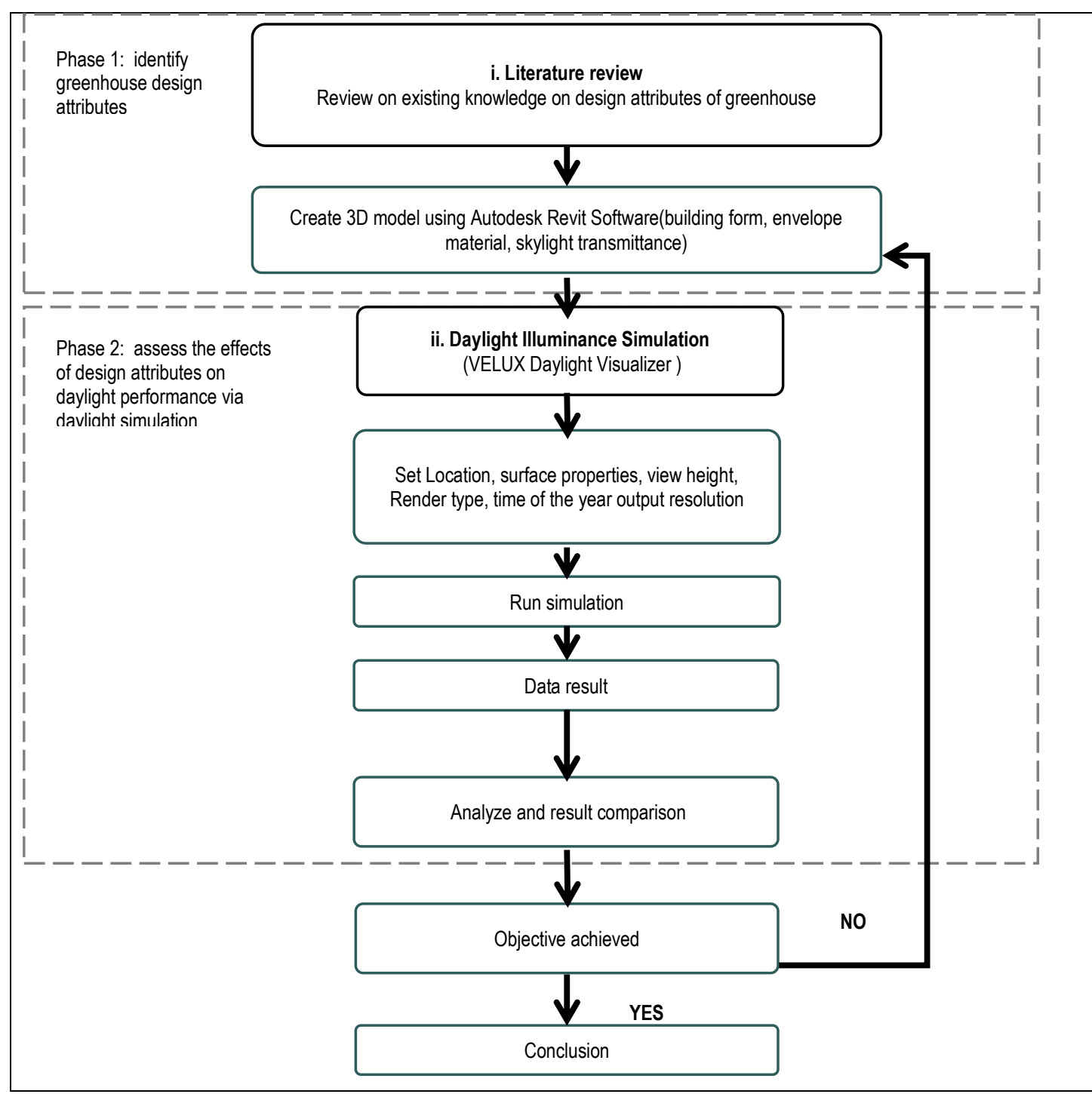

Figure 1: Research Flow Chart (Source: Author)

\subsection{Study area}

The site of the simulated greenhouse buildings is at the same location, in Sekinchan, Selangor. The building dimensions are $48 \mathrm{~m}$ (Length) $\times 19 \mathrm{~m}$ (Width) $\times 4 \mathrm{~m}$ (Height). The greenhouse is designed with three bays of slightly pitched roof. Three building configurations are selected:

i) Building $A$ is the control building without shading,

ii) Building $B$ has shading on the façade

iii) Building $\mathrm{C}$ has shading on the façade with a reduced number of skylights

All three building models have the same orientation, location and form. All three building models have a gross floor area of $2529.9 \mathrm{sqm}$. The site location is set at $101.112 \mathrm{E}, 3.492 \mathrm{~N}$ in both simulations. 


\subsection{Building Configuration using Revit}

A greenhouse building is proposed in the Malaysian lowland area. The three-dimensional (3D) model of the building is created using Revit Architecture. Building modelling involves the following steps:

i) Three units of greenhouse 3D models (buildings A, B and C) are created in Autodesk Revit software.

- Building $A$ is proposed with skylight and does not have any additional façade shading.

- Then, Building B is proposed with additional façade shading with the same number of skylights as Building A.

$\circ$ Building $C$ is proposed with additional façade shading same as Building $B$ with fewer skylight than Building $B$.

ii) The building types, are set based on Table 3

iii) The location of buildings A, B and C is established using Internet Mapping Service inbuilt in Autodesk Revit located in Sekinchan, Selangor. (Latitude 3.4926 Longitude, 101.1126 altitudes 2m).

Table 3 Proposed greenhouse configurations.

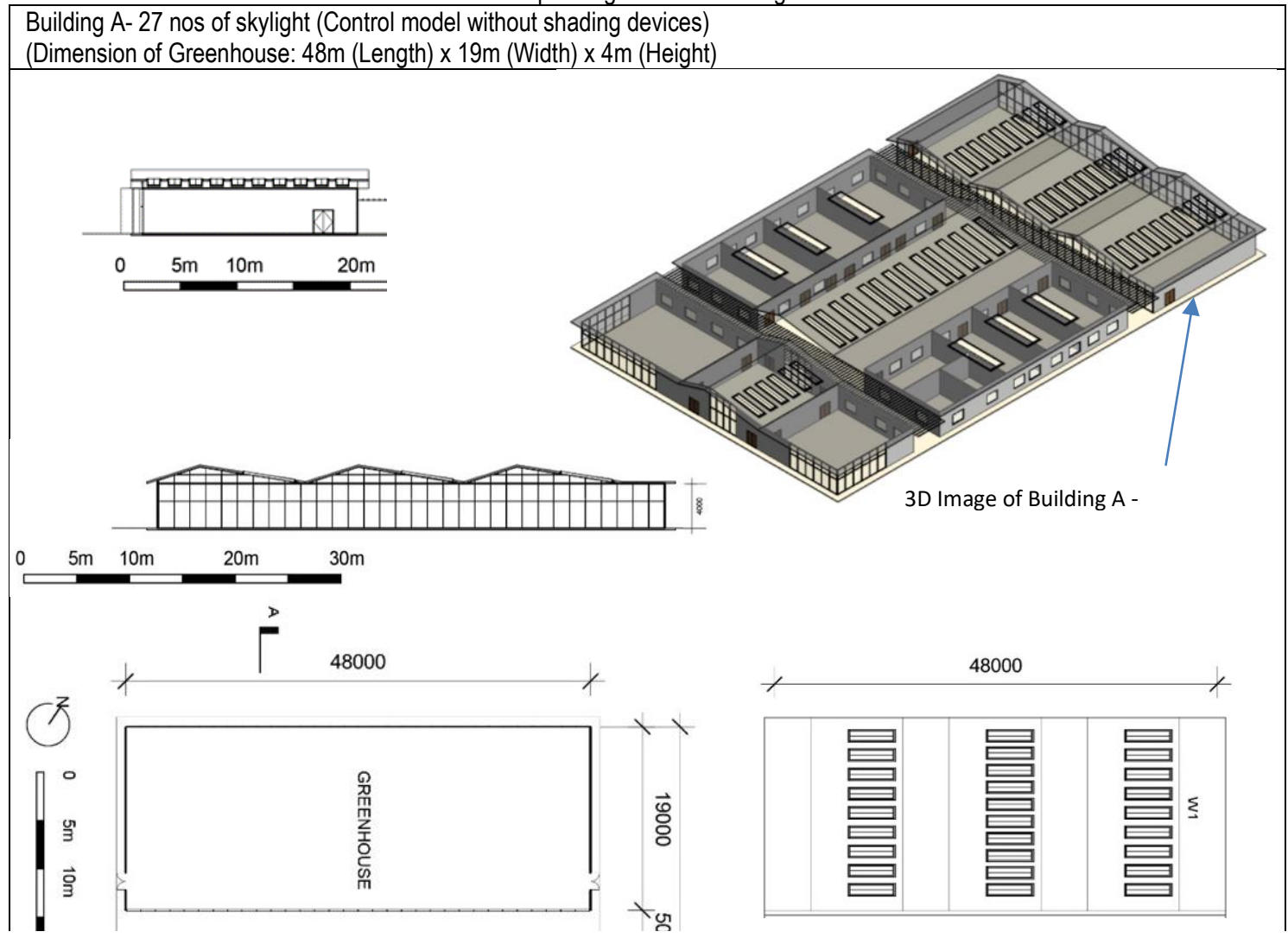




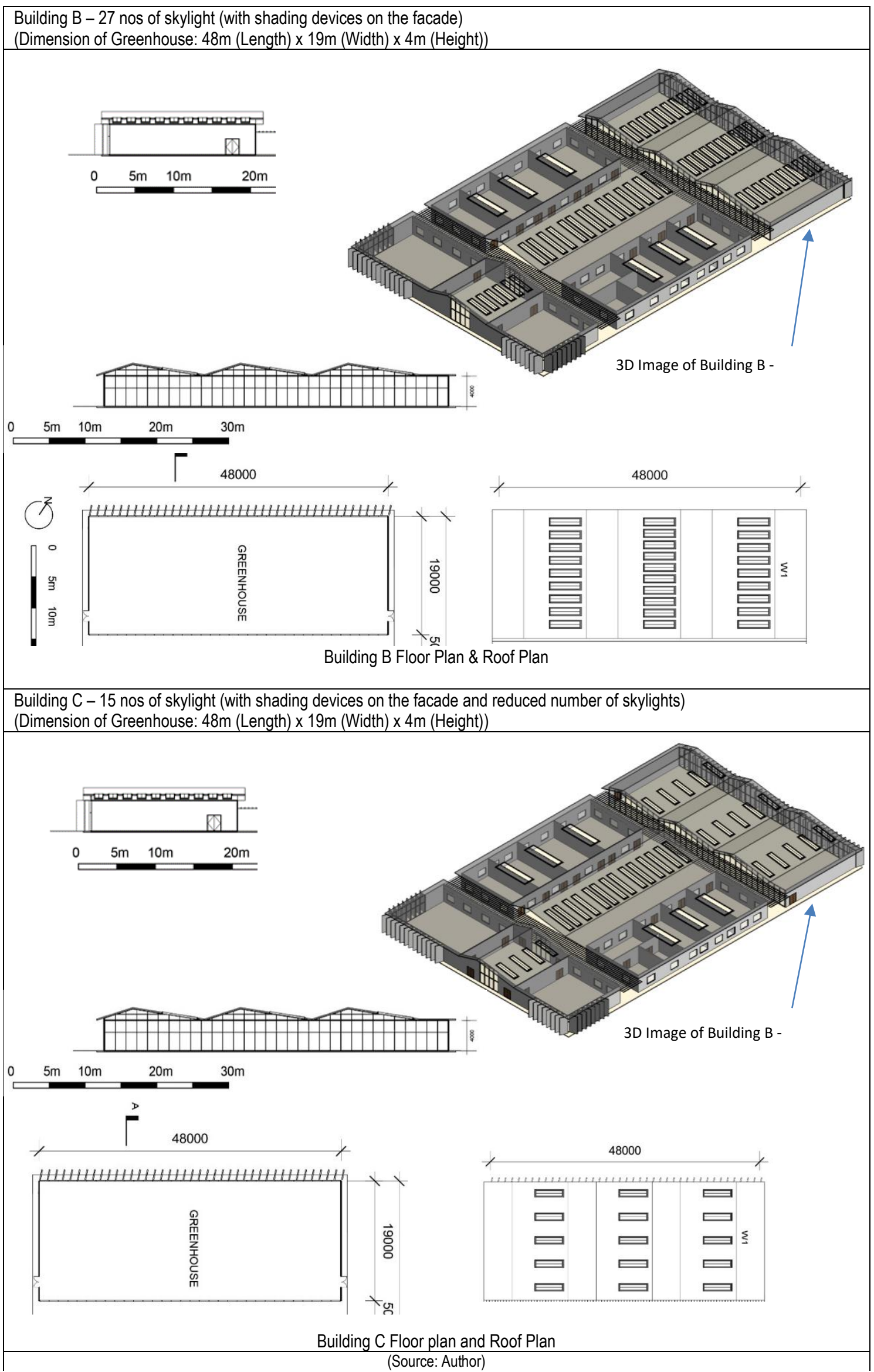


The skylight names and dimensions are given in Table 4.

Table 4: Skylight dimension

\begin{tabular}{ll}
\hline Skylight name & Dimension \\
\hline W1 & $1200 \mathrm{~mm} \times 5000 \mathrm{~mm}$ \\
W2 & $2400 \mathrm{~mm} \times 8000 \mathrm{~mm}$ \\
W3 & $1200 \mathrm{~mm} \times 7000 \mathrm{~mm}$ \\
W4 & $12000 \mathrm{~mm} \times 5000 \mathrm{~mm}$ \\
\hline
\end{tabular}

\subsection{Envelope material}

The building materials for Building $A$ are specified in Table 5 . The building materials for Building $B$ and $C$ are specified based on Table 6 with better $u$-value compared with building $A$.

\begin{tabular}{|c|c|c|}
\hline Category & Override & Analytic Construction \\
\hline Roofs & $\square$ & Waterproof covering, screed, cast concrete, dense plaster $\left(\mathrm{U}=2.0500 \mathrm{~W} /\left(\mathrm{m}^{2} \cdot \mathrm{K}\right)\right)$ \\
\hline Exterior Walls & $\square$ & 4 in heavyweight concrete block $\left(\mathrm{U}=2.4866 \mathrm{~W} /\left(\mathrm{m}^{2} \cdot \mathrm{K}\right)\right)$ \\
\hline Interior Walls & $\square$ & 4 in heavyweight concrete block $\left(\mathrm{U}=2.9625 \mathrm{~W} /\left(\mathrm{m}^{2} \cdot \mathrm{K}\right)\right)$ \\
\hline Ceilings & $\square$ & Plaster, wood boards, glass wool on joists $\left(\mathrm{U}=0.8226 \mathrm{~W} /\left(\mathrm{m}^{2} \cdot \mathrm{K}\right)\right)$ \\
\hline Floors & $\square$ & Vinyl, screed, concrete - $\mathrm{A}\left(\mathrm{U}=2.0100 \mathrm{~W} /\left(\mathrm{m}^{2} \cdot \mathrm{K}\right)\right)$ \\
\hline Slabs & $\square$ & Standard slab construction - B $\left(\mathrm{U}=0.4063 \mathrm{~W} /\left(\mathrm{m}^{2} \cdot \mathrm{K}\right)\right)$ \\
\hline Doors & $\square$ & Wood panel $\left(\mathrm{U}=3.8042 \mathrm{~W} /\left(\mathrm{m}^{2} \cdot \mathrm{K}\right)\right)$ \\
\hline Exterior Windows & $\square$ & $1 / 8$ in Pilkington single glazing (U-value 5.5473) $\left(\mathrm{U}=5.5473 \mathrm{~W} /\left(\mathrm{m}^{2} \cdot \mathrm{K}\right), \mathrm{SHGC}=0.86\right)$ \\
\hline Interior Windows & $\square$ & $1 / 8$ in Pilkington single glazing (U-value 5.5473) $\left(\mathrm{U}=5.5473 \mathrm{~W} /\left(\mathrm{m}^{2} \cdot \mathrm{K}\right), \mathrm{SHGC}=0.86\right)$ \\
\hline Skylights & $\square$ & Large single-glazed Window $\left(\mathrm{U}=6.7018 \mathrm{~W} /\left(\mathrm{m}^{2} \cdot \mathrm{K}\right), \mathrm{SHGC}=0.86\right)$ \\
\hline
\end{tabular}

Table 6 Building analysis properties for building B and building C (Source: Author)

\subsection{Daylight illuminance simulations Velux Daylight Visualizer}

For this study, Daylight Visualizer is used to simulate the illuminance of the internal spaces. This illuminance data collection is essential to determine the daylighting quality of the interior spaces, under the intermediate sky conditions. It leads to decision making on the suitability of crop arrangements inside the proposed greenhouse. Firstly, the 3D model is imported from the Revit software. The envelope material is defined, where glazing material is set for $68 \%$ transmittance for the greenhouse area. Wall, floor and ceiling finishes are set as a white matte material finish. The view plan is set as $850 \mathrm{~mm}$ from floor finishes. The simulations are set hourly on $21 \mathrm{st}$ May between 08:00h and 17:00h under intermediate sky condition (external illuminance of $20000 \mathrm{Lux}$ ). The process is repeated for the other 3D models. The data is then tabulated and analysed.

\subsection{Scope and limitation}

This study only focuses on the façade shading, envelope materials and the number of skylights. The purpose is to identify better greenhouse design to be implemented in tropical lowland of Malaysia in daylight illuminance and intensity. Figure 2 shows the asymmetric roof form for the greenhouse area is selected based on the literature review.

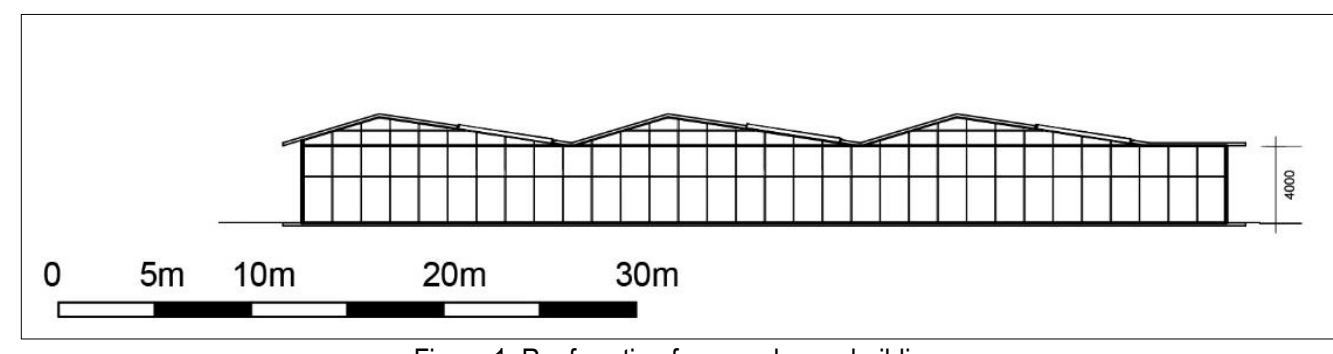

Figure 1: Roof section for greenhouse building

(Source: Author)

Each simulation does not consider any adjacent building and vegetation but responds to the specified microclimate in Sekinchan, Selangor. This study uses Autodesk Revit simulation tool for all the simulations on the related subject used for building modelling and Velux Daylight Visualizer for daylight simulations and analysis. The daylight analysis only focuses on the façade shading and the number of skylights. The reading is taken from the plan to locate suitable areas to place the crop beds. The electrical lighting fixture is not 
included in the simulation as it focuses on the daylight illuminance only. The simulation experiment excluded the furniture, as a generalisation in setting the furniture layout is not foreseen.

\subsection{Findings}

\subsection{Daylight illuminance simulations using Velux Daylight Visualizer}

Building $A$ is simulated with skylight and without any additional façade shading. Next, Building $B$ is simulated with additional façade shading and the same number of skylights as Building $A$. Then Building $C$ is simulated with the same additional façade shading as Building $B$ and a smaller number of skylights than Building $B$.

Table 1 shows the greenhouse light requirement used as the benchmark. The average daylight illuminance is set at 1000 lux. 1000 lux is the benchmark for the greenhouse area for growing edible plants. The result is analysed based on the given illuminance contour and average lux inside the greenhouse.

\subsection{Daylight illuminance in the Greenhouse}

Daylight illuminance data from physical model case studies are presented graphically in the form of contours with different daylight illuminance plotted over a building floor plan as shown in Table 4. Figure 3 shows the quantitative results of the daylight simulations of the greenhouse in terms of daylight illuminance in lux. Here the different shading configurations without varying the building form, area, window opening, and orientation are tested.

Table 4: Daylight simulation result for the greenhouse area

\begin{tabular}{|c|c|c|c|}
\hline Time & Building A & Building B & Building C \\
\hline 0800 & Average lux : 1784.99 & Average lux : 1358.60 & Average lux : 995.46 \\
\hline lux & & & \\
5,000 & & & \\
4,375 & & & \\
3,750 & & & \\
3,125 & & & \\
2,500 & & & \\
1,876 & & & \\
6251 & & & \\
\hline
\end{tabular}

At 8 am the obtained results indicate that the daylight penetration depth is more in Building A compared with Buildings B and C. Only building $A$ and Building $B$ passed the requirement for plants with small sunlight claim at 08:00.

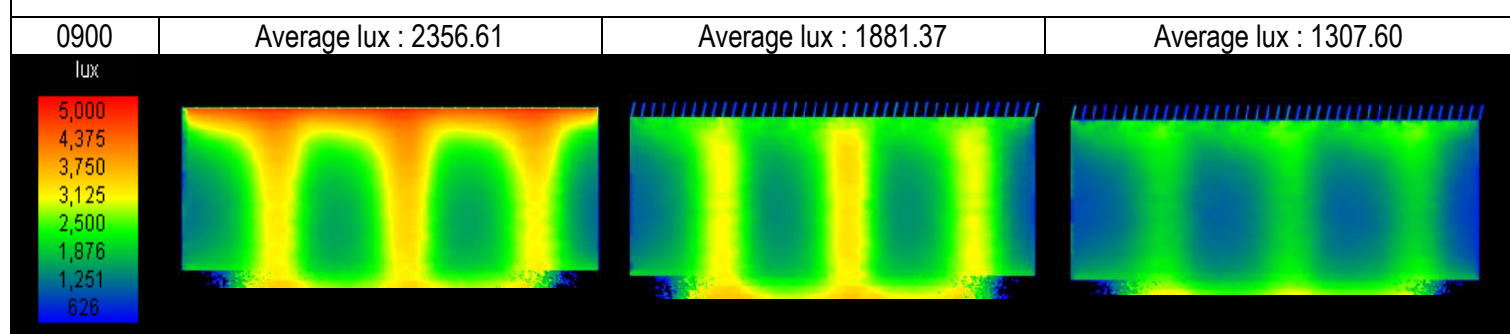

At 9 am the obtained results indicate that the daylight penetration depth is more in Building $A$ compared with Building $B$ and Building $C$. Here, all the three greenhouses passed the requirement for plants with small sunlight claim at 09:00.

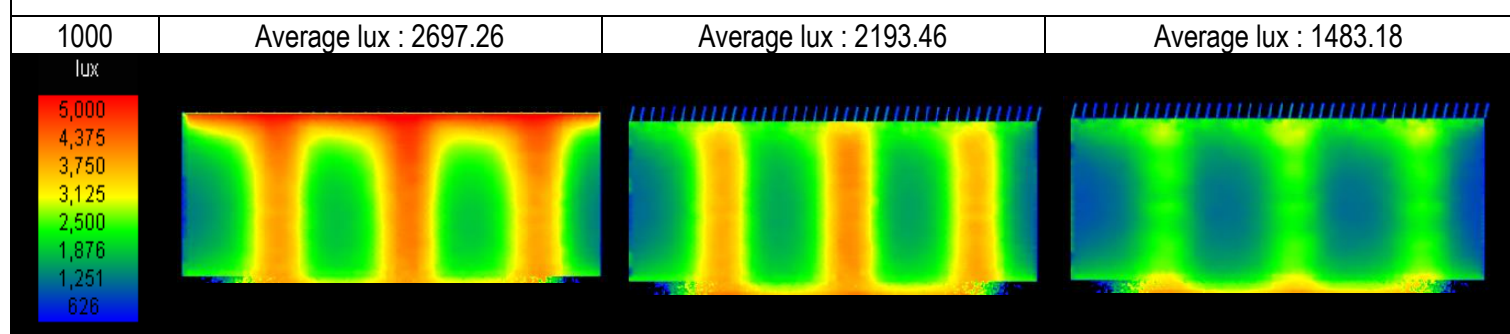

At 10 am Buildings $A$ and $B$ achieved an average lux of more than 2000 lux, while Building $C$ achieved an average lux of 1483.18 lux. Buildings $A$ and $B$ have high daylight intensity up to 4000 lux located under the skylight. Meanwhile, Building $C$ has daylight intensity of 2500 lux under the skylight. Here, all the three greenhouses passed the requirement for plants with small sunlight claim during this hour.

\begin{tabular}{l|l|l|l}
1100 & Average lux : 2757.12 & Average lux : 2394.31 & Average lux : 1634.24
\end{tabular}




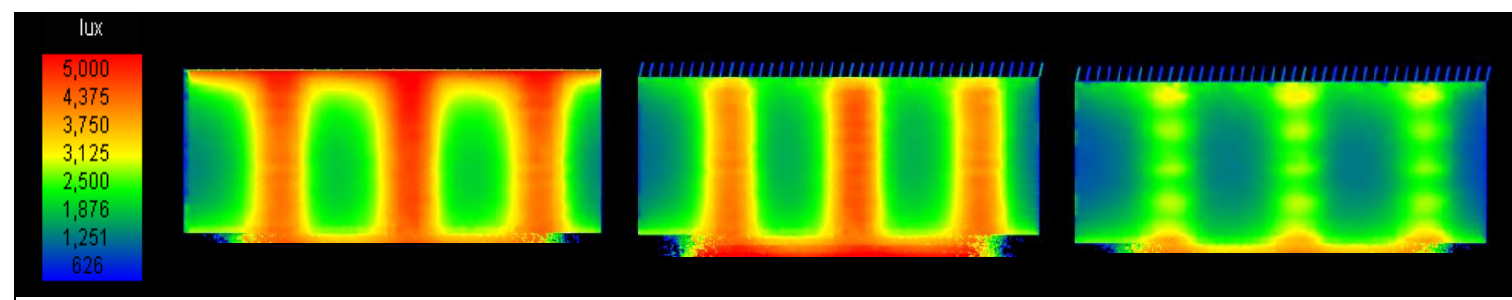

At 11 am Buildings $A$ and B recorded an average lux of more than 2000 lux, while Building $C$ achieved an average lux of 1634.24 lux. Buildings $A$ and $B$ have high daylight intensity up to 5000 lux located under the skylight suitable for growing less demanding plants (root, bulb, cabbage, leafy peas). Meanwhile, Building $C$ has daylight intensity up to 2500 lux under the skylight. Here, all the three greenhouses passed the requirement for plants with small sunlight claim at $11 \mathrm{am}$.

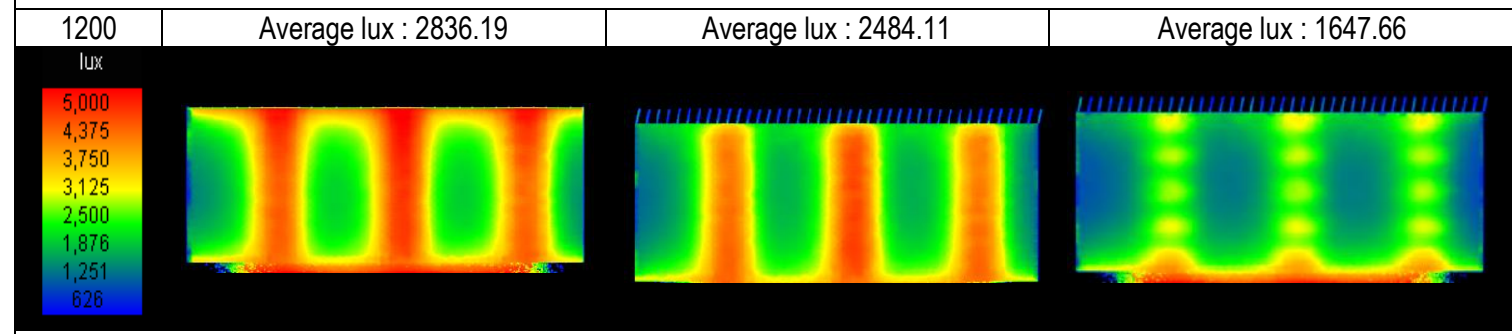

At noon, Building A recorded the highest light intensity than Building B and Building $\mathrm{C}$. Here, the three greenhouses passed the lighting requirement for plants with small sunlight claim at noon.

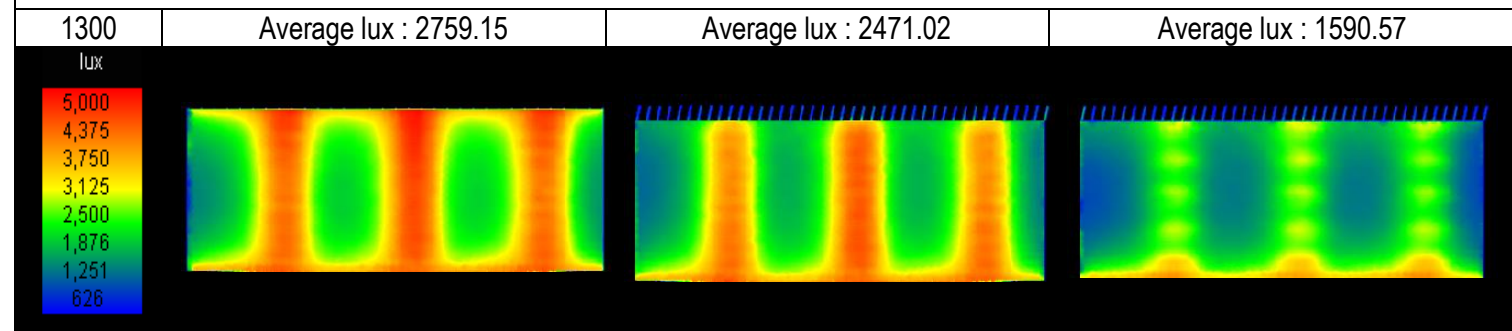

At 1 pm Buildings A and B recorded high daylight intensity up to 5000 lux located under the skylight suitable for growing less demanding plants (root, bulb, cabbage, leafy peas). Meanwhile, Building $C$ has daylight intensity up to 2500 lux under the skylight. Here, all the three greenhouses passed the requirement for plants with small sunlight claim at $1 \mathrm{pm}$.

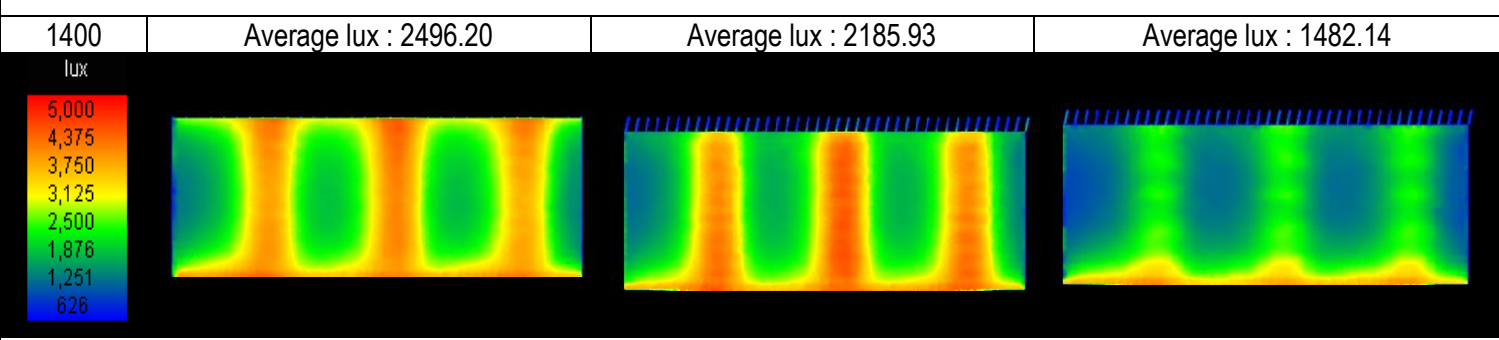

At 2 pm Building A and B recorded high daylight intensity up to 4000 lux located under the skylight suitable for growing less demanding plants (root, bulb, cabbage, leafy peas). Meanwhile, Building $C$ has daylight intensity up to 2500 lux under the skylight. Here, all the three greenhouses passed the requirement for plants with small sunlight claim at $2 \mathrm{pm}$.

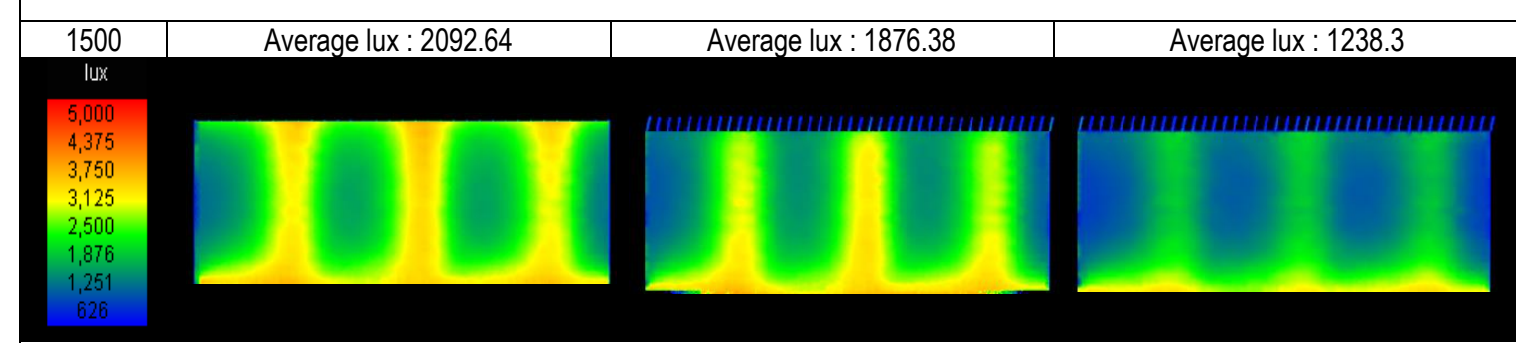

At 3 pm Buildings $A$ and $B$ have high daylight intensity up to 3000 lux located under the sunlight. Meanwhile, Building $C$ has daylight intensity up to 2000 lux under the skylight.

\begin{tabular}{|l|l|l|l|}
\hline 1600 & Average lux : 1560.83 & Average lux : 1337.37 & Average lux : 947.66 \\
\hline
\end{tabular}




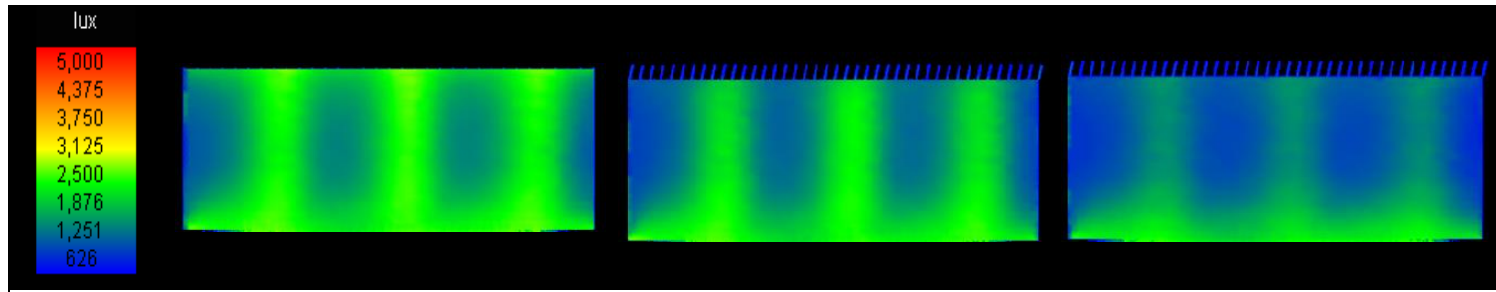

At $4 \mathrm{pm}$ the results indicate that the daylight penetration depth is more in Building A compared with Buildings $\mathrm{B}$ and $\mathrm{C}$. Only buildings $A$ and $B$ passed the requirement for plants with small sunlight claim of 1000 lux at $4 \mathrm{pm}$.

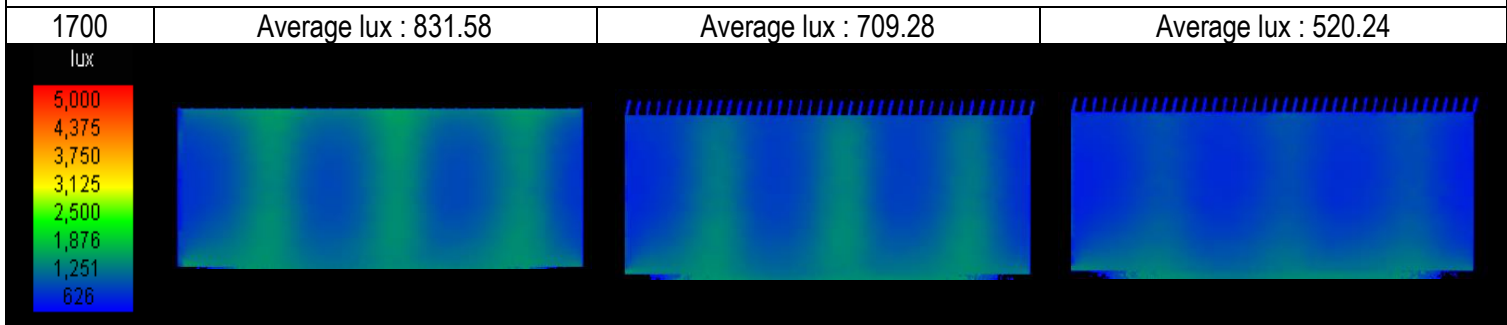

At $5 \mathrm{pm}$ Buildings $\mathrm{A}, \mathrm{B}$ and $\mathrm{C}$ recorded a low amount of daylight penetration at this hours with average daylight illuminance reading less than 1000 lux. Here, all three greenhouses did not meet the minimum requirement for plants with small sunlight claim at $5 \mathrm{pm}$.

$\mathrm{F}$

\begin{tabular}{|c|c|c|c|c|c|c|c|c|c|c|}
\hline & \multicolumn{10}{|c|}{} \\
\hline
\end{tabular}

Figure 3: Average Daylight illuminance of proposed greenhouse building (Source: Author)

\subsection{Daylighting Performance of the Greenhouses}

The comparisons of the daylight performance for the greenhouse confirms it is unnecessary to shade the north-south wall of the greenhouse. The baseline greenhouse (Building A) without shading passed the requirement for plants with small sunlight claim between the hours of 8:00 and 16:00 with illuminance levels between 1000lux (at $8 \mathrm{am}$ ) and 2836 lux (noon). Buildings $A$ and $B$ have an average illuminance reading of more than 1000 lux for 9 hours and Building $C$ for 7 hours. 7 hours of daylight is enough for medium sunlight and low sunlight plant type as too much sunlight exposure can also damaging the crops (Source: Kim, 2019). There is an opportunity to increase the size of glazing at a small section of the greenhouse. The increased skylight glazing size is to cater for higher daylight demanding plants (potatoes, bulbs cabbage, leafy peas etc) that needs $4000-7000$ lux (Table 1). The number of skylights has a higher impact on average daylight illuminance reading than additional façade shading 


\subsection{Conclusion}

The focus of this paper is to explore the design attributes of greenhouses to allow efficient greenhouse operation. The location of the study is at an agricultural low land in Sekinchan, Selangor. The climatic condition is hot-humid tropical condition.

The objectives and outcomes of this study are:

i) To identify design attributes of a greenhouse such as dimension, shapes, orientation and location of building, building shading strategies. The design attributes identified are the envelope roof shape, U-value envelope material, number of skylight placement and shading devices as cooling strategy influence the crop production environment.

ii) To assess the effects of design attributes on the greenhouse daylight performance in a hot and humid climate. Based on the result, the use of a shading device and fewer skylight number reduces the average daylight that penetrates the building. Greenhouse plant production in a hot- humid climate is suitable for plants with small sunlight claim.

The use of Daylight VELUX Visualizer allows consideration of the vegetation bed, equipment and furniture placement in the greenhouse for the habitable area. In this study, the number of skylights has a larger effect in reducing the average daylight illuminance reduction rate than adding façade shading devices. The baseline greenhouse (Building A) without shading passed the requirement for plants with small sunlight claim with illuminance levels between 1000lux (at 8 am) and 2836 lux (noon) up to 9 hours.

Employing building simulation tool such as Daylight VELUX Visualizer) for data collection shows how design parameters affect building daylight illumination distribution. This paper concludes that the higher number of skylight dominates the solar illumination compared with the external shading. Furthermore, facade shading on the Northeast wall of the greenhouse is unnecessary. The application of facade shading and lower number of skylight results in a reduction of daylight illuminance.

\section{Recommendations for future studies}

Future studies could explore the roof skylight and opening placement, building orientation or the roof structure configuration for specific crop production. The simulations of façade shading devices such as shading devices thickness, shapes, and material are areas for future research

\section{Acknowledgement}

The authors wish to acknowledge the Master of Architecture Programme at the Centre of Studies for Architecture, Faculty of Architecture, Planning and Surveying, UiTM for the support to accomplish this paper. We also acknowledge UNAM, Mexico City for the ongoing research collaboration. The authors are also thankful to Autodesk and VELUX for providing free software used in this study.

\section{Paper Contribution to Related Field of Study}

This study could benefit architects, engineers, agriculturists, and researchers in material, shape and design attributes selection for greenhouse design decision in addressing climate change. Computer simulation allows a better understanding of daylight illuminance behaviour in greenhouses, especially in Malaysian hot-humid climate. Thus efficient daylight and energy usage can be obtained.

\section{References}

Abdel-Ghany, A. M., Al-Helal, I. M., \& Shady, M. R. (2016). Estimating the Thermal Radiative Properties of Shading Nets under Natural Outdoor Conditions. Journal of Heat Transfer, 138(9), 1-6. https://doi.org/10.1115/1.4032953

Asiabanpour, B., Estrada, A., Ramirez, R., \& Downey, M. S. (2018). Optimizing Natural Light Distribution for Indoor Plant Growth Using PMMA Optical Fiber: Simulation and Empirical Study. Journal of Renewable Energy, 2018, 1-10. https://doi.org/10.1155/2018/9429867

Bodolan, C., \& Brătucu, G. (2013). Heat and Light Requirements of Vegetable Plants. 5th International Conference "Computational Mechanics and Virtual Engineering " COMEC 2013, October, 361-364.

Department of Occupational Safety and Health. (2018). Guidelines On Occupational Safety And Health For Lighting At Workplace

Ghani, S., Bakochristou, F., ElBialy, E. M. A. A., Gamaledin, S. M. A., Rashwan, M. M., Abdelhalim, A. M., \& Ismail, S. M. (2019). Design challenges of agricultural greenhouses in hot and arid environments - A review. Engineering in Agriculture, Environment and Food, 12(1), 48-70. https://doi.org/10.1016/j.eaef.2018.09.004

Ghani, S., El-Bialy, E. M. A. A., Bakochristou, F., Mohamed Rashwan, M., Mohamed Abdelhalim, A., Mohammad Ismail, S., \& Ben, P. (2020). Experimental and numerical investigation of the thermal performance of evaporative cooled greenhouses in hot and arid climates. Science and Technology for the Built Environment, 26(2), 141-160. https://doi.org/10.1080/23744731.2019.1634421

Husain, F. H., Abdul Aziz, A., Yuhaniz, M., \& Sh. Ahmad, S. (2020). A Review of Aspects and Criteria of Daylighting and Visual Comfort in International Green Building Rating Tools. Environment-Behaviour Proceedings Journal, 5(15), 151-157. https://doi.org/10.21834/ebpj.v5i15.2492

Kim Toscano. (August 6, 2019). A Gardener's Guide to Sun Exposure. Southerrn Living Plant Collection.Retrieved at https://southernlivingplants.com/planting-care/agardeners-guide-to-sun-exposure/

Mohapatra, B., Kumar, M. R., Mdl, K., \& Mandal, S. K. (2018). ANALYSIS OF DAYLIGHTING USING DAYLIGHT FACTOR AND LUMINANCE FOR. October. 
Pakari, A., \& Ghani, S. (2019). Evaluation of a novel greenhouse design for reduced cooling loads during the hot season in subtropical regions. Solar Energy, 181(February), 234-242. https://doi.org/10.1016/j.solener.2019.02.006

Shamshiri, R., \& Ismail, W. I. W. (2014). Investigation of Climate Control Techniques for Tropical Lowland Greenhouses in Malaysia. Journal of Applied Sciences, 14(1), 60-65. https://doi.org/10.3923/jas.2014.60.65

Shamshiri, R. R., Kalantari, F., Ting, K. C., Thorp, K. R., Hameed, I. A., Weltzien, C., Ahmad, D., \& Shad, Z. (2018). Advances in greenhouse automation and controlled environment agriculture: A transition to plant factories and urban agriculture. International Journal of Agricultural and Biological Engineering, 11(1), 1-22. https://doi.org/10.25165/j.jijabe.20181101.3210

Yunus, J., Ahmad, S. S., \& Zain-Ahmed, A. (2010). Analysis of atrium's architectural aspects in office buildings under tropical sky conditions. CSSR $2010-2010$ International Conference on Science and Social Research, Cssr, 536-541. https://doi.org/10.1109/CSSR.2010.5773836 